\title{
AN OVERVIEW OF SCHEDULED WASTES MANAGEMENT IN MALAYSIA
}

\author{
Noor Artika H*, Yusof MZ and Nor Faiza MT \\ Department of Community Medicine, Kulliyyah of Medicine, International Islamic University Malaysia, 25200, Kuantan, Pahang \\ *Corresponding Author E-mail: noor_artika@iium.edu.my
}

This is an open access article distributed under the Creative Commons Attribution License, which permits unrestricted use, distribution, and reproduction in any medium, provided the original work is properly cited.

\section{ARTICLE DETAILS}

Article History:

Received 19 August 2019 Accepted 23 September 2019 Available online 11 October 2019

\begin{abstract}
The article reviews the scheduled waste management in Malaysia. It describes the scheduled waste classifications, characteristics, the sources of scheduled wastes, the policies and regulations related to scheduled wastes, the management of scheduled wastes in Malaysia and the challenges related to scheduled waste management in Malaysia. Currently, the manufacturing industry has contributed the highest scheduled waste production in Malaysia. Under the Environmental Quality Act (EQA) 1974, the government has set up several legal provisions specifically for scheduled waste generation, storage, transportation, and disposal. The aims are to reduce the potential risks to human and the environment. The paradigm shift from cradle to grave to cradle to cradle concept is a sustainable and sound concept which is inevitable step to minimize the scheduled waste generation in Malaysia.
\end{abstract}

\section{KEYWORDS}

waste management, scheduled waste classifications, Environmental Quality Act (EQA), transportation.

\section{INTRODUCTION}

Malaysia is a developing country and ranked the world's $22^{\text {nd }}$ most competitive economy [1]. As a country involved in a lot of industrial activities such as manufacturing, construction, agriculture, mining and quarrying, hazardous wastes are unavoidable. In Malaysia, hazardous waste is defined as scheduled waste. Scheduled wastes are any unwanted matters whether in solid, semi-solid, liquid, or gases which if emitted, released, deposited or discharged to environment, can be a potential hazard to human and the environment. This is referred to the waste materials that are specified in the "First Schedule of Regulation 2, Environmental Quality (Scheduled Wastes) Regulations 2005". There are 77 types of scheduled wastes listed under the First Schedule of Environmental Quality (Scheduled Wastes) Regulations 2005 and are divided into 5 categories namely:
\end{abstract}

\begin{tabular}{|c|c|c|}
\hline i. & SW 1 & $\begin{array}{l}\text { Metal and metal-bearing wastes (10 types of } \\
\text { scheduled wastes); }\end{array}$ \\
\hline ii. & SW 2 & $\begin{array}{l}\text { Wastes containing principally inorganic } \\
\text { constituents which may contain metals and organic } \\
\text { materials ( } 7 \text { types of scheduled wastes); }\end{array}$ \\
\hline iii. & SW 3 & $\begin{array}{l}\text { Wastes containing principally organic constituents } \\
\text { which may contain metals and inorganic materials } \\
\text { ( } 27 \text { types of scheduled wastes); }\end{array}$ \\
\hline iv. & SW 4 & $\begin{array}{l}\text { Wastes which may contain either inorganic or } \\
\text { organic constituents ( } 32 \text { types of scheduled wastes) }\end{array}$ \\
\hline v. & SW 5 & Other wastes ( 1 type of scheduled waste) \\
\hline
\end{tabular}

In 1987, the scheduled wastes generated in Malaysia was 400 thousand tonnes, however there was no specific institution to manage the scheduled wastes. The wastes increased to one million tonnes in 2008 and grew to 1.88 million tonnes in 2010 [2,3]. In 2017, the quantity of scheduled waste generated in Malaysia was 2.02 million tonnes and the largest contributor was from the manufacturing industry [4]. It increased by $7 \%$ compared to 2010 . The sources of scheduled wastes can be from several sectors such as health, industrial, manufacturing, agricultural and households. In the health sectors, it produces medical wastes such as disposable items contaminated with biological agents, expired drugs, chemical wastes, radioactive dyes, and sharps waste. The industrial and manufacturing sector use chemical materials while the agricultural sector is involved with pesticides, herbicides and fertilizer which can contaminate the surface of water and underground water. Household products also generate scheduled wastes such as fluorescent light, toxic paints, pesticides, solvents etc. Technology has evolved and currently, besides all these wastes, the new challenge is to manage electric and electronic wastes (e-wastes). The examples of e-wastes are medical devices, dispensers, toys, sport equipment, batteries, plastic casings, circuit boards and activated glass [5].

\section{METHODOLOGY}

All articles related to scheduled wastes were screened during the period of January 1, 2000 to December 31, 2018, using the following sources: PubMed, Google Scholar, and The Lancet, and were limited to articles written in English. Due to limited studies that had been conducted in Malaysia, the duration of articles collected were within the last 20 years. Besides journals, the authors also reviewed guidelines and books related to scheduled wastes in Malaysia. Several combination keywords were used, including scheduled waste in Malaysia, hazardous waste in Malaysia, scheduled waste management in Malaysia, hazardous waste management in Malaysia, and issues and challenges related to scheduled and hazardous wastes.

\section{HAZARDOUS WASTES CHARACTERISTICS}

[1] The USEPA under Code of Federal Regulations (CFR) defined the waste as hazardous if it has one or more of the following characteristics which are ignitability, corrosivity, toxicity, reactivity, or infectious or pathogenic. The criteria of each characteristic is described in Table 1 [6]. The waste generator and workers involved with the scheduled wastes should comprehend the nature, properties and characteristics of the hazardous wastes so that they will take extra precaution during handling, storage and transportation. 
Table 1: The characteristics of hazardous wastes

\begin{tabular}{|c|c|c|}
\hline Characteristics & Criteria & Examples of scheduled wastes \\
\hline \multirow[t]{6}{*}{ Ignitability } & Combustible, flammable and sustain combustion & $\begin{array}{l}\text { SW } 303 \text { - Adhesive or glue containing organic solvents } \\
\text { excluding polymeric materials }\end{array}$ \\
\hline & If the waste is a liquid and has flash point less than $600^{\circ} \mathrm{C}(1400 \mathrm{~F})$ & SW 322 - Waste of nonhalogenated organic solvents \\
\hline & $\begin{array}{l}\text { Capable under standard temperature and pressure, of causing fire } \\
\text { through friction }\end{array}$ & $\begin{array}{l}\text { SW } 325 \text { - Uncured resin waste containing organic } \\
\text { solvents }\end{array}$ \\
\hline & It is an ignitable compressed gas & $\begin{array}{l}\text { SW } 416 \text { - Sludges of inks, paints, pigments, lacquer, dye } \\
\text { or varnish. }\end{array}$ \\
\hline & It is an oxidizer & $\begin{array}{l}\text { SW } 417 \text { - Waste of inks, paints, pigments, lacquer, dye or } \\
\text { varnish. }\end{array}$ \\
\hline & & $\begin{array}{l}\text { SW } 432 \text { - Waste containing, consisting of or } \\
\text { contaminated with peroxides }\end{array}$ \\
\hline \multirow[t]{4}{*}{ Corrosivity } & $\begin{array}{l}\text { Acidic or alkaline with } \mathrm{pH} \text { less than or equal to } 2 \text {, or greater than or } \\
\text { equal to } 12.5\end{array}$ & SW 206 - Spent inorganic acids \\
\hline & $\begin{array}{l}\text { Corrodes steel at a rate greater than } 6.35 \mathrm{~mm}(0.250 \mathrm{inch}) \text { per year at a } \\
\text { test temperature of } 550 \mathrm{C}(1300 \mathrm{~F}) .\end{array}$ & $\begin{array}{l}\text { SW } 201 \text { - Spent organic acids with pH less or equal to } 2 \\
\text { which are corrosive or hazardous }\end{array}$ \\
\hline & & SW 401 - Spent alkalis containing heavy metals \\
\hline & & $\begin{array}{l}\text { SW } 402 \text { - Spent alkalis with pH more or equal to } 11.5 \\
\text { which are corrosive or hazardous }\end{array}$ \\
\hline \multirow[t]{7}{*}{ Reactivity } & $\begin{array}{l}\text { Waste is normally unstable and readily undergoes violent changes } \\
\text { without detonating. }\end{array}$ & $\begin{array}{l}\text { SW } 317 \text { - Spent organometallic compounds including } \\
\text { tetraethyl, tetramethyl lead and organotin compounds }\end{array}$ \\
\hline & If the waste reacts violently with water & $\begin{array}{l}\text { SW } 431 \text { - Waste from manufacturing or processing or } \\
\text { use of explosives }\end{array}$ \\
\hline & If the waste form potentially explosive mixtures with water. & \\
\hline & $\begin{array}{l}\text { If the waste when mixed with water generates toxic gases, vapours or } \\
\text { fumes to cause danger to human health or the environment. }\end{array}$ & \\
\hline & $\begin{array}{l}\text { If the cyanide or sulfide bearing waste when exposed to } \mathrm{pH} \text { between } 2 \\
\text { and } 11.5 \text { generates toxic ases, vapours or fumes }\end{array}$ & \\
\hline & Capable to cause detonation or explosion & \\
\hline & $\begin{array}{l}\text { Readily capable to cause detonation or explosive decomposition or } \\
\text { reaction at standard temperature and pressure. }\end{array}$ & \\
\hline \multirow[t]{7}{*}{ Toxicity } & $\begin{array}{l}\text { Toxicity characteristic if it exceeds specified concentrations of certain } \\
\text { metals and organic compounds as listed by reference in the regulations. }\end{array}$ & SW 101 Waste containing arsenic or its compound. \\
\hline & $\begin{array}{l}\text { The waste or its extract has any of the contaminants listed in the } \\
\text { Guidelines For The Application Of Special Management of Scheduled } \\
\text { Waste }\end{array}$ & $\begin{array}{l}\text { SW } 104 \text { Dust, slag, dross or ash containing aluminium, } \\
\text { arsenic, mercury, lead, cadmium, chromium, nickel, } \\
\text { copper, vanadium, beryllium, antimony, tellurium, } \\
\text { thallium or selenium excluding slag from iron and steel } \\
\text { factory. }\end{array}$ \\
\hline & & SW 109 Waste containing mercury or its compound \\
\hline & & $\begin{array}{l}\text { SW } 204 \text { Sludges containing one or several metals } \\
\text { including chromium, copper, nickel, zinc, lead, cadmium, } \\
\text { aluminium, tin, vanadium and beryllium }\end{array}$ \\
\hline & & $\begin{array}{l}\text { SW } 318 \text { Waste, substances and articles containing or } \\
\text { contaminated with Polychlorinated biphenyls (PCB) or } \\
\text { polychlorinated triphenyls (PCT). }\end{array}$ \\
\hline & & SW 320 Waste containing formaldehyde. \\
\hline & & SW 407 Waste containing dioxins or furans \\
\hline \multirow[t]{3}{*}{$\begin{array}{l}\text { Infectious } \\
\text { or Pathogenic }\end{array}$} & $\begin{array}{l}\text { Any waste which consists wholly or partly of human or animal tissue, } \\
\text { blood or other body fluids, excretions, drugs }\end{array}$ & $\begin{array}{l}\text { SW } 403 \text { Discarded drugs containing psychotropic } \\
\text { substances or containing substances that are toxic, } \\
\text { harmful, carcinogenic, mutagenic or teratogenic }\end{array}$ \\
\hline & $\begin{array}{l}\text { Other pharmaceutical products, swabs or dressings, syringes, needles or } \\
\text { other sharp instruments, being waste which unless rendered safe may } \\
\text { prove hazardous to any person coming into contact with it }\end{array}$ & $\begin{array}{l}\text { SW } 404 \text { Pathogenic wastes, clinical wastes or } \\
\text { quarantined materials }\end{array}$ \\
\hline & & $\begin{array}{l}\text { SW } 405 \text { Waste arising from the preparation and } \\
\text { production of pharmaceutical product }\end{array}$ \\
\hline
\end{tabular}




\section{MALAYSIAN SCHEDULED WASTE MANAGEMENT AND POLICY}

Environmental Quality Act of 1974 is a provision for prevention, abatement, control and protection of the environment, which is administered by the Department of Environment. The EQA was enforced in 1975 and had been amended in 1976, 1985, and 1996 parallel with the international standards. In the 1980's, there were no scheduled waste facilities in Malaysia which led to waste dumping in the refuse disposal sites. The improper management of scheduled wastes in that period lead to the contamination of the groundwater and surface water, and air pollution which caused adverse effects on the environment and human health. The impacts of scheduled wastes is described in Figure 1.

In the sixth and Eight Malaysian Plan, the government has strengthened the regulations related to scheduled wastes. They promoted the tax rebate to companies who comply with the regulations and introduced penalties to industries which are non-compliant with the regulations.

As yet, Malaysia has developed a comprehensive legal provision related to the management of scheduled wastes. The regulation is based on the cradle to grave principle and currently had been shifted to cradle to cradle principle. A facility which generates, stores, transports, treats or disposes scheduled wastes is subject to the following main regulations [7]:

- $\quad$ Environmental Quality (Scheduled Wastes) Regulations 2005 (Amendment) 2007;

- $\quad$ Provision in Section 34B, Environmental Quality Act 1974

- Environmental Quality (Prescribed Conveyance) (Scheduled Wastes) Order 2005;

- Environmental Quality (Prescribed Premises) (Scheduled Wastes Treatment and Disposal Facilities) (Amendment) Order 2006;

- Environmental Quality (Prescribed Premises) (Scheduled Waste Treatment and Disposal Facilities) (Amendment) Regulations 2006:

- Environmental Quality (Prescribed Activities) (Environmental Impact Assessment) Order 2015;

- Customs (Prohibition of Exports) Order 1998 (Amendment) 2008; and

- $\quad$ Customs (Prohibition of Imports) Order 1998 (Amendment) 2008.

Scheduled wastes can be stored for 180 days or less depending on the waste generation which shall not exceed 20 metric tonnes. If the waste generator would like to store more than the permissible limit, they should write a letter to Director General of Department of Environment Malaysia. Every container should be clearly labelled with the date of waste generated, name, address and phone number of the waste generator.

\section{SCHEDULED WASTE MANAGEMENT FACILITIES}

The types of scheduled wastes handled by the operators determine the management facilities that should be taken. The facilities include off-site storage and waste transfer stations, transportation of the scheduled wastes, secure landfill, incineration plant including for clinical wastes, offsite physio-chemical waste treatment facilities for scheduled wastes stabilization or solidification before being placed in landfills, centralized waste treatment facilities, resource recovery, land treatment and waste water treatment facilities. The establishment of the management facilities need license through the Department of Environment.

In Malaysia, Kualiti Alam had established the centralized integrated scheduled waste management centre and was granted the exclusive right to operate the plant for 15 years. They are responsible for waste collection, transportation, treatment, and final disposal of hazardous wastes [8]. They process all types of scheduled wastes except radioactive waste, pathological waste and explosive waste. Multiple technologies are used in the treatment and disposal depending on types of scheduled wastes which comprise incineration plants, physical and chemical treatment plants, solidification treatment plants, secure landfills and clinical waste treatment centres.

The incineration plant is suitable for organic wastes such as hazardous, toxic, clinical and pathological wastes in all forms which requires thermal treatment for destruction efficiency. The rotary kiln with the primary and secondary chambers are operating at temperatures above $1000^{\circ} \mathrm{C}$ to ensure the highest possible destruction efficiency, followed by heat recovery system and finally an extensive multi-stage flue-gas treatment system. Kualiti Alam produced 14,000 metric tons of bottom ash as a result of incineration process and disposed to secured landfills [9]. There were several controversial issues regarding the incinerator such as the emission of dioxin that can cause air pollution and the risk of dioxin contamination to the water supply $[10,11]$. Besides this issues, the safety of secured landfill have also been questioned although it is covered by a low density polyethylene liner. Several other objections are because the incineration process will not destroy $100 \%$ of the pollutants, and during the burning process, it can yield new products which might be more dangerous than the original wastes [12].

Research showed the most sustainable method of managing the ash was through the controlled low-strength material (CLSM) which mixed up the slurry by mixing sand, cement, ash, and water. This process is called the stabilisation and solidification process in which it will bind them into a solid matrix [13]. It is very effective in managing the inorganic wastes for example metal hydroxide sludge which usually contain lead, arsenic nickel, zinc and chromium and not allowed for direct disposal into secured landfill. This plant is very useful to treat large amounts of scheduled wastes.

Physical \& Chemical Treatment Plant (PCT) will handle all types of inorganic liquid wastes. It is usually used in combination with thee solidification process to transform the scheduled wastes into a less harmful product. These wastes are treated through several chemical processes such as neutralisation, oxidation and reduction.

There are several companies that process the clinical wastes such as Kualiti Alam, Faber Medi-Serve Sdn Bhd, Pantai Medivest Sdn Bhd, and Radicare (M) Sdn Bhd. The current technology is the AMS-serial 250Ecosteryl which is the microwave disinfection system. It has zero emission system and has no harmful effects. Compared to incinerator, it does not involve combustion and does not produce water, steam, odour, and smoke. It can process the maximum quantity of $300 \mathrm{~kg}$ per hour and the residue can be placed in the landfill. Besides this method, incinerator is still used in Malaysia to manage the clinical wastes.

The secured landfill is the final option for scheduled wastes. After all the scheduled wastes had been treated, it will be placed in the secured landfill. It is equipped with the monitoring sensor to prevent contamination to the environment.

\section{PARADIGM SHIFT FROM CRADLE TO GRAVE TO CRADLE TO} CRADLE CONCEPT

Previously, Malaysia adopted the cradle to grave method or end of pipe approaches in which the processes begin from the extraction of the raw materials, the manufacturing process, followed by the use of the products and finally the disposal of the products. It gives priority for disposal rather than resource recovery in which it can lead to environmental concerns due to increasing sites for secured landfill, leachate problems, illegal dumping and air pollution [14].

However, the emphasis in recent years has shifted to cleaner production and zero discharge engineering which is aimed for pollution prevention and therefore, the concept cradle to cradle was introduced. The aim was to minimize waste by either reusing the products or recycling it into different products with no loss of quality in a close-loop cycle. Cradle to cradle concept will transform a product into a new product of equal, if not greater, function and value. The example is a bottle that contains a specific chemical, and after the chemicals finished, it can be used to store the wastes of the same chemicals. Converting to a cradle to cradle technology will protect the natural resources and reduce the scheduled waste generation in Malaysia.

\section{CHALLENGES OF SCHEDULED WASTE IN MALAYSIA}

Management of scheduled waste is one of the most critical environmental issue in Malaysia. The cost to dispose the scheduled wastes are quite expensive and therefore, there are a lot of illegal dumping cases in Malaysia. The worst case in Malaysia was Sungai Kim-Kim which occurred in March until August 2019. There were several waves of air pollution in that area which affected more than 5000 people including hundreds of students and children $[15,16]$. The chemicals detected in the air were methane, toluene, xylene, ethylbenzene, and D-Limonene which can lead to acute poisoning and the long term effects are still unknown. To date, the prosecution is still on-going.

Improper knowledge on scheduled waste handling can transmit a lot of diseases. In particular to clinical waste, the obstacles include the handling of non-segregated waste, collection of the waste, facilities and storage, operational cost and documentations as well as awareness of the waste generator [17]. The problem may also arise on technical knowledge and competencies of the waste handler and lack of transfer station for waste management [18]. 
For E-waste, there is no proper disposal mechanism that has been introduced to encourage the public to discard e-waste properly in Malaysia. The focus is mainly on the practice in larger industries but not among the public. The current guideline related to e-waste issued by the Department of Environment, Malaysia does not comprehensively give the information to the end user on the management of the e-waste after the end of the electrical equipment life span. Indirectly, it will reflect on lack of awareness among public to dispose the e-waste properly [19]. Consequently, they tend to dispose e-waste in incinerators or solid waste landfills together with other wastes [20]. Thus, it is important to ensure the public is well-informed about handling e-waste.

\section{CONCLUSION}

Close monitoring of the industries is needed to ensure that all the waste generators are following the regulations stated under the EQA 1974. There are still a lot of challenges to be tackled to reduce illegal dumping and incompliance of regulations. Cradle to cradle is the most sustainable approach for Malaysia and can only be achieved if the waste generators can give commitment and cooperation for government's target.

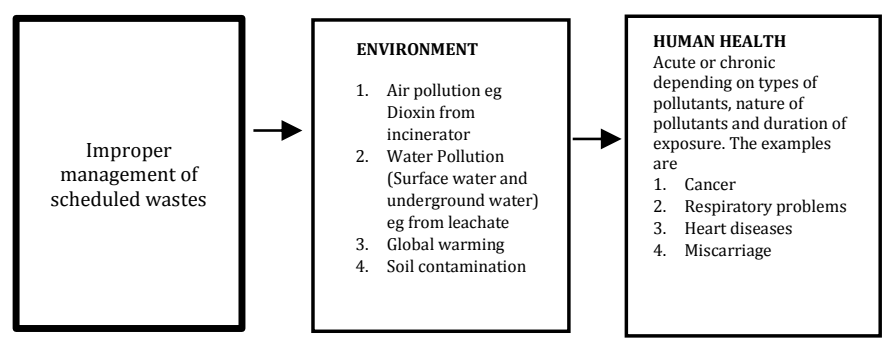

Figure 1: The Impacts of scheduled wastes to environment and human health

\section{REFERENCES}

[1] Bernama. 2019. Malaysia remains the world's 22nd most competitive economy. New straits times.

[2] Aja, O.C. 2016. Overview of Hazardous Waste Management Status in Malaysia, 69-87.

[3] Department of statistics. 2018. Compendium of Environment Statistics.

[4] Department of statistics. 2015. Compendium of Environment Statistics.

[5] Grant, K., Goldizen, F. C., Sly, P. D., Brune, M. N., Neira, M., van den Berg, M., Norman, R. E. 2013. Health consequences of exposure to e-waste: a systematic review. The lancet global health, 1(6), e350-e361.
[6] Environment Institute of Malaysia (EiMAS) Department of Environment. 2015. Guidebook on the Identification and Classifications Scheduled Waste. EiMAS

[7] Legal Research Board. Environmental Quality Act 1974(Act 127), Regulations, Rules \& Orders. International Law Book Services.

[8] Ishak, M. B. 2002. The law of industrial waste management in Malaysia," in International Conference on Waste Management and The Environment, Cádiz, Spain, 643-651.

[9] Razak, H. A. Naganathan, S. Hamid, S. N. A. 2009. Performance appraisal of industrial waste incineration bottom ash as controlled lowstrength material, Journal of Hazardous Materials, 172, 862-867, $12 / 30 / 2009$

[10] Abad, E., Adrados, M. A., Caixach, J., Fabrellas, B., Rivera, J. 2000. Dioxin mass balance in a municipal waste incinerator. Chemosphere, 40(911), 1143-1147.

[11] Lang, G., Xu, Y. 2013. Anti-incinerator campaigns and the evolution of protest politics in China. Environmental Politics, 22(5), 832-848.

[12] Corrigan, R. 2011. Ireland and Incineration-A Very Long Engagement. Critical social think-ing: policy and practice, 3 .

[13] Sari, N. M. 2015. Mercury Waste Management in Malaysia Preliminary Analysis, D. o. E. Malaysia, Ed., ed. Kuala Lumpur: United Nations Environment Programme.

[14] Jamin, N. C., Mahmood, N. Z. 2015. Scheduled Waste Management in Malaysia: An Overview. Advanced Materials Research, 1113.

[15] Goh, Y.H. 2019. Pasir Gudang chemical spill: Facts about the 9 chemicals found and their health impact.

[16] The Straits Time. 2019. Pasir Gudang pollution caused by leftover toxic waste from Sungai Kim Kim.

[17] Razali, S. S., Ishak, M. B. 2010. Clinical waste handling and obstacles in Malaysia. Journal of Urban and environmental Engineering, 4(2), 47-54.

[18] Ambali, A. R., Bakar, A. N. 2012. Medical waste management in Malaysia: Policies, strategies and issues. In 2012 IEEE Colloquium on Humanities, Science and Engineering (CHUSER), 672-677. IEEE.

[19] Kalana, J. A. 2010. Electrical and electronic waste management practice by households in Shah Alam, Selangor, Malaysia. International Journal of Environmental Sciences, 1(2), 132-144.

[20] Agamuthu, P., Victor, D. 2011. Policy trends of extended producer responsibility in Malaysia, Waste Management \& Research, 29(9), 945953 